\title{
Factors causing rickets in institutionalised handicapped children on anticonvulsant therapy
}

\author{
YUICHIRO MORIJIRI AND TAMOTU SATO \\ Department of Paediatrics, School of Medicine, Kanazawa University, Japan
}

SUMMARY An epidemiological study on vitamin D-dependent rickets was carried out in severely handicapped institutionalised children on long-term anticonvulsant therapy. Nine $(10 \%)$ of 94 patients had overt rickets on the basis of roentgenological bone changes and biochemical indices, but 46 patients in hospital without medication, and 50 epileptic patients attending an outpatient clinic and taking anticonvulsants had no sign of rickets. Causative factors for the development of rickets were evaluated. Administration of anticonvulsive drugs depressed the serum 25-hydroxyvitamin D (25-OHD) level, but this was not the major factor in the development of rickets. Vitamin D intake seemed to be about average in these patients and its supplementation increased their serum 25-OHD level. This serum 25-OHD level was not maintained by supplemental vitamin D, unless the children were exposed to sunlight. These results indicate that although several factors--such as anticonvulsants, low vitamin D intake, and inactivity-are concerned in the development of rickets, the main cause is lack of sun in institutionalised handicapped children.

Association of vitamin D-dependent rickets, or osteomalacia, with long-term treatment with anticonvulsant drugs is well known. Such drugs presumably enhance hepatic conversion of 25hydroxyvitamin $\mathrm{D}$ (25-OHD) to biologically inactive metabolites, resulting in depression of serum 25-OHD level. In our experience epileptic outpatients receiving anticonvulsant drugs rarely show evidence of rickets, although handicapped children in hospital who receive such treatment have a high incidence of overt rickets. A recent report suggested that the association of anticonvulsant therapy with rickets might occur by chance or it might be related to the inactivity of the patients. ${ }^{1}$ Evidence was presented to show that the serum 24,25-dihydroxyvitamin $\mathrm{D}$ concentrations were appreciably depressed but that 25-OHD levels were almost normal in epileptics. ${ }^{2}$ Because of these conflicting findings, an epidemiological study of vitamin D-dependent rickets in institutionalised severely handicapped children was done. The contribution of dietary vitamin D intake, the kind of anticonvulsant drugs, the effect of exposure to sunlight, and lack of physical activity to the development of rickets was evaluated in relation to serum 25-OHD levels.

\section{Materials and methods}

The patients comprised 140 severely handicapped children with cerebral palsy in three (A, B, and C) national hospitals in Ishikawa prefecture, 94 of whom were being treated with anticonvulsant drugs. Fifty epileptic outpatients and 38 age-matched normal children served as the controls. Each child was placed in one of three groups according to his mobility: in group 0 the children were unable to crawl and were confined to bed; in group 1 the children could crawl or move in wheelchairs; in group 2 the children could walk (Table 1). All epileptic patients had been taking phenobarbitone, phenytoin, primidone, or acetazolamide, or a combination of these, for at least 2 years (Fig. 1). Some children took phenobarbitone, some took phenytoin, and some a combination of these two

Table 1 Details of the children

\begin{tabular}{|c|c|c|c|c|}
\hline & \multirow{2}{*}{$\begin{array}{l}\text { Age (years) } \\
(\text { mean } \pm S D)\end{array}$} & \multicolumn{3}{|c|}{ Mobility of children* } \\
\hline & & Group 0 & Group 1 & Group 2 \\
\hline $\begin{array}{l}\text { Children in hospital } \\
\text { On anticonvulsants } \\
(n=94) \\
\text { No drugs }(n=46) \\
\text { Children not in hospital } \\
\text { Epileptics on } \\
\text { anticonvulsants } \\
(n=50) \\
\text { Controls }(n=38)\end{array}$ & $\begin{array}{l}11 \cdot 6 \pm 7 \cdot 5 \\
10 \cdot 5 \pm 6 \cdot 6\end{array}$ & $\begin{array}{l}63(67) \\
24(52)\end{array}$ & $\begin{array}{l}15(16) \\
12(26)\end{array}$ & $\begin{array}{l}16(17) \\
10(22)\end{array}$ \\
\hline
\end{tabular}

* Group 0 unable to crawl and confined to bed, group 1 able to crawl or in wheelchair, group 2 able to walk.

Percentages are given in brackets 


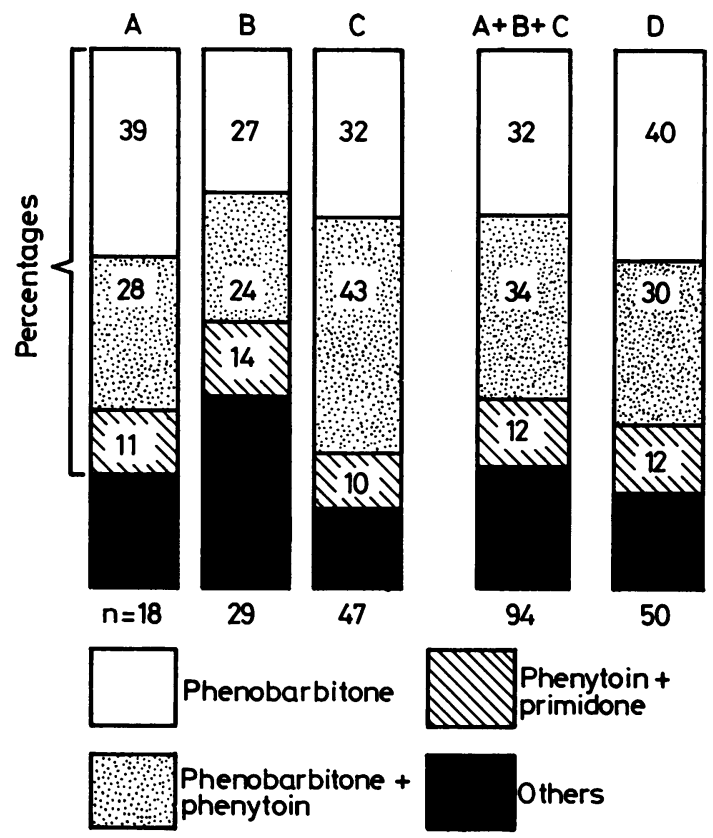

Fig. 1 Distribution of anticonvulsant drugs in the handicapped children at $A, B$, and $C$ hospitals and in outpatients at $D$ hospital.

drugs, but the distribution was about the same at each hospital and in the outpatients. Therefore the groups were comparable in regard to the type of medication. Blood samples were obtained from all patients and controls between May and June 1978. Serum calcium (Ca), ${ }^{*}$ phosphorus $(\mathrm{P})$, alkaline phosphatase (Alk-P), and 25-OHD concentrations were determined. Changes in wrist bones were examined roentogenologically in all patients. Clinical diagnosis of rickets was based on rachitic changes in the bone characteristic of the disease, and a clearly

*The samples were determined by Tecnicon AA-2. raised Alk-P level with decreased $\mathrm{Ca}$ or P. Serum 25-OHD was measured by using a modification of competitive protein-binding assay, as described by Belsey et al. $^{3}$ Binding protein was prepared by a $1: 40000$ dilution of rachitic rat serum. The sensitivity of this method was $1.0 \mathrm{ng} / \mathrm{ml}$. The coefficient of variation of interassay and intra-assay was 12 and $5 \cdot 8 \%$, respectively.

Dietary intakes of $\mathrm{Ca}$ and vitamin $\mathrm{D}$ were estimated by measuring the daily food supply at each hospital for one week and calculating the $\mathrm{Ca}$ and vitamin D content. After rhis had been done, patients in A hospital were given 400 IU and patients in B hospital $200 \mathrm{IU}$ each day of vitamin D2, and the effect of this on the serum 25-OHD level was studied. To examine the effect of sunlight on the serum 25-OHD level, patients in A and B hospitals were given sunbaths for between 60 and 90 minutes each week from August 1978 to July 1979, but in B hospital the sunbath was stopped during the winter as a control period. Statistical analysis was carried out by Student's $t$ test.

\section{Results}

Incidence of rickets and biochemical data (Table 2). Clinically overt rickets was found in $9(6 \%)$ of 140 patients in hospital. The incidence for the group on anticonvulsants was $9(10 \%)$ per 94 . The combination of phenobarbitone and phenytoin was most often administered but a particularly damaging drug could not be singled out. However, the patients in hospital who were not being treated with anticonvulsants had no rachitic signs, nor had the outpatients. All the patients with rickets were unable to walk: 8 were in group 0 , and 1 was in group 1 . They showed clear changes in serum $\mathrm{Ca}, \mathrm{P}$, Alk-P, and 25-OHD level $(2 \cdot 6+1.7 \mathrm{ng} / \mathrm{ml}$, mean $\pm \mathrm{SD})$. In the children being treated in hospital, serum $\mathrm{Ca}$, $\mathrm{P}$, and 25-OHD concentrations were significantly lower and Alk-P higher than those in the controls $(\mathrm{P}<0.01$ to 0.001$)$; and their reduced 25-OHD levels were also significant compared with those of

Table 2 Serum 25-OHD and electrolyte values (mean $\pm S D$ ) in the children

\begin{tabular}{|c|c|c|c|c|}
\hline & $\begin{array}{l}\text { Calcium } \\
(m g / 100 m l)\end{array}$ & $\begin{array}{l}\text { Phosphorus } \\
\text { (mg/100ml) }\end{array}$ & $\begin{array}{l}\text { Alkaline phospha- } \\
\text { tase (KA units) }\end{array}$ & $\begin{array}{l}25-O H D \\
(n g / m l)\end{array}$ \\
\hline \multicolumn{5}{|l|}{ Children in hospital } \\
\hline $\begin{array}{l}\text { On anticonvulsants }(n=94) \\
\text { (Rickets) }(n=9) \\
\text { No drugs }(n=46)\end{array}$ & $\begin{array}{l}8 \cdot 8 \pm 0 \cdot 9^{*} \\
7 \cdot 9 \pm 0 \cdot 8^{*} \\
8 \cdot 8 \pm 1 \cdot 0^{*}\end{array}$ & $\begin{array}{l}3 \cdot 8 \pm 0 \cdot 8^{*} \\
2 \cdot 7 \pm 0 \cdot 4^{*} \\
3 \cdot 9 \pm 0 \cdot 7^{*}\end{array}$ & $\begin{array}{l}28 \pm 34^{* *} \\
99 \pm 53^{*} \\
12 \pm 5\end{array}$ & $\begin{array}{l}7 \cdot 7 \pm 4 \cdot 4^{*} \dagger \\
2 \cdot 6 \pm 2 \cdot 9^{*} \\
9 \cdot 5 \pm 4 \cdot 6^{*}\end{array}$ \\
\hline \multicolumn{5}{|l|}{ Children not in hospital } \\
\hline $\begin{array}{l}\text { Epileptics on anticonvulsants }(n=50) \\
\text { Controls }(n=38)\end{array}$ & $\begin{array}{l}9.6 \pm 0.6 \\
9 \cdot 7 \pm 0.6\end{array}$ & $\begin{array}{l}4 \cdot 7 \pm 0 \cdot 6 \\
4 \cdot 7 \pm 0 \cdot 6\end{array}$ & $\begin{array}{l}23 \pm 7 \cdot 5^{*} \\
12 \pm 6\end{array}$ & $\begin{array}{l}15 \cdot 8 \pm 8 \cdot 4^{*} \\
23 \cdot 0 \pm 8 \cdot 4\end{array}$ \\
\hline
\end{tabular}

*P $<0.001, * * P<0.01 \mathrm{v}$ control.

+P $0.05 \mathrm{v}$ children in hospital without drugs.

Conversion: traditional units to $S I-25-O H D: 1 \mathrm{ng} / \mathrm{ml} \approx 2 \cdot 50 \mathrm{nmol} / 1$. Calcium: $1 \mathrm{mg} / 100 \mathrm{ml} \approx 0.25 \mathrm{mmol} / 1$.

Phosphorus: $1 \mathrm{mg} / 100 \mathrm{ml} \approx 0.326 \mathrm{mmol} / 1$. 
children in hospital not on drugs $(P<0 \cdot 05)$. Furthermore a slight but significant rise in Alk-P and a decrease in 25-OHD level was noted in outpatients on anticonvulsants $(P<0.001 \mathrm{v}$ controls $)$. Therefore, the lowering effect of anticonvulsants on serum 25-OHD concentration is apparent, and such drugs play a causative role in the development of rickets.

Daily intake of vitamin $\mathrm{D}$ and $\mathrm{Ca}$ in relation to the incidence of rickets (Table 3). Ca intake was similar in all hospitals and satisfied the daily need for children ( 0.5 to $0.7 \mathrm{~g} /$ day). Vitamin $D$ intake varied considerably in each hospital: 70, 30, and $110 \mathrm{IU}$ in $\mathrm{A}, \mathrm{B}$, and $\mathrm{C}$ respectively. But a control value of vitamin D intake examined in a general children's hospital was similar to that of hospital C (Table 3, hospital D), so that these levels of intake were about average except in the case of B hospital. Serum 25-OHD was also significantly lower in the patients in B hospital. However, there was little correlation between mean daily intake of vitamin $D$ in a particular hospital and the prevalence of rickets. Therefore, the level of vitamin D in the diet may not be an important factor in causing rickets in the patients.

Effect of vitamin D supplements and exposure to sunlight on serum 25-OHD (Figs 2 and 3). In the handicapped child, sunlight exposure is limited because the child is confined to bed, and will stay indoors throughout most of his life. Therefore, a regular schedule of sunbaths for between 60 and 90 minutes each week was started. With supplements of vitamin D and sunbaths, serum 25-OHD level rose significantly from $7 \cdot 3 \pm 4 \cdot 1$ to $18 \cdot 4 \pm 5 \cdot 7 \mathrm{ng} / \mathrm{ml}$ in A hospital, and from $7 \cdot 1 \pm 5 \cdot 1$ to $15 \cdot 5 \pm 10 \cdot 5 \mathrm{ng} / \mathrm{ml}$ in $B$ hospital $(P<0.001)$. The regular sunbath and

Table 3 Comparison of daily intakes of calcium and vitamin $D$, and serum 25-OHD levels (mean $\pm S D$ ) in 4 hospitals and the prevalence of rickets

\begin{tabular}{|c|c|c|c|c|}
\hline & \multicolumn{4}{|l|}{ Hospital } \\
\hline & $\boldsymbol{A}$ & $B$ & $C$ & $D+$ \\
\hline \multicolumn{5}{|l|}{ Daily intake } \\
\hline $\begin{array}{l}\text { Calcium (g) } \\
(n=7)\end{array}$ & $0 \cdot 9 \pm 0 \cdot 2$ & $0.5 \pm 0.1$ & $0.6 \pm 0 \cdot 1$ & $0 \cdot 7 \pm 0 \cdot 1$ \\
\hline Vitamin D (IU) & & & & \\
\hline $\begin{array}{l}(n=7) \\
\text { Serum 25-OHD }\end{array}$ & $70 \pm 50$ & $30 \pm 20$ & $110 \pm 80$ & $70 \pm 80$ \\
\hline \multicolumn{5}{|l|}{$\begin{array}{l}\text { Serum 25-OHD } \\
\text { (ng/ml) }\end{array}$} \\
\hline vulsants & $\begin{array}{l}7 \cdot 3 \pm 5 \cdot 0 \\
(n=18)\end{array}$ & $\begin{array}{l}6 \cdot 1 \pm 4 \cdot 5 \\
(n=29)\end{array}$ & $\begin{array}{l}8 \cdot 8 \pm 4 \cdot 0^{*} \\
(n=47)\end{array}$ & - \\
\hline No drugs & $\begin{array}{l}7 \cdot 5 \pm 2 \cdot 5 \\
(n=9)\end{array}$ & $\begin{array}{l}8 \cdot 7 \pm 5 \cdot 6 \\
(n=18)\end{array}$ & $\begin{array}{l}12 \cdot 1 \pm 3 \cdot 0^{* *} \\
(n=19)\end{array}$ & - \\
\hline \multicolumn{5}{|c|}{ Number of patients } \\
\hline with rickets & 1 & 5 & 3 & \\
\hline
\end{tabular}

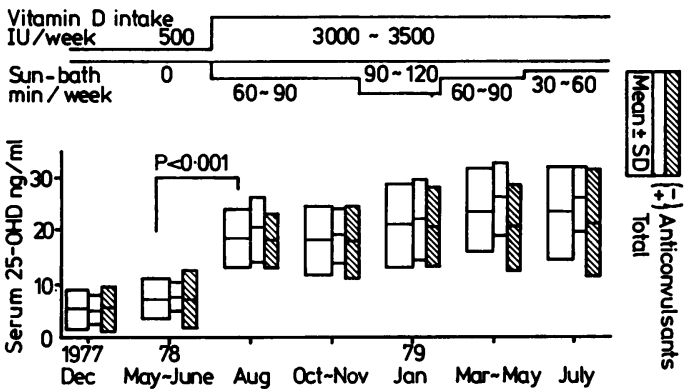

Fig. 2 Serum levels of 25-OHD at follow-up in the patients in A hospital. With supplementation of vitamin $D$ and sunbath, the level of 25-OHD rose and maintained the normal level throughout the observation period.

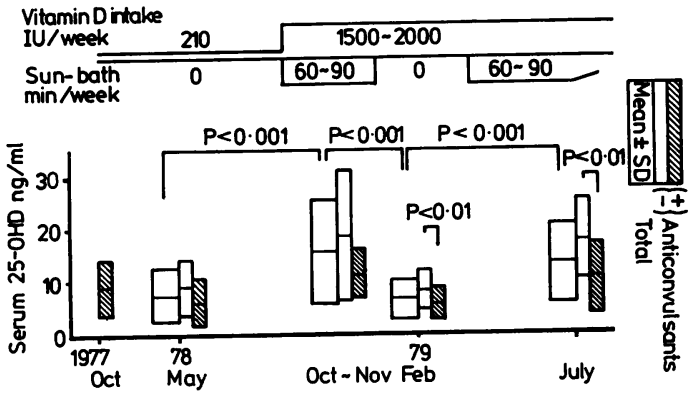

Fig. 3 Serum levels of 25-OHD at follow-up in the patients in B hospital. When exposure to sun was stopped during the winter the 25-OHD fell to its earlier level despite adequate doses of vitamin $D$. The level of 25-OHD returned to its higher level when sunbaths were resumed.

vitamin D administration maintained serum 25-OHD level within the normal range throughout the observation period in A hospital, but when sunbaths were stopped during the winter in B hospital there was a decrease of 25-OHD to the previous level despite an adequate vitamin $D$ supplementation. Administration of anticonvulsant drugs did not apparently correlate with the fluctuation of serum 25-OHD levels. During this period overt rickets did not develop in these children. These results suggest that sunlight is a more important factor for the activation of vitamin $D$ and the maintenance of serum 25-OHD concentration than supplements of vitamin D.

\section{Discussion}

Raised serum Alk-P levels were first detected in epileptic patients receiving long-term anticonvulsant treatment. ${ }^{4}$ Since then, in several reports attention has been paid to the association of osteomalacia with 
drugs. Such studies have demonstrated that chronic phenobarbitone administration in man and animals produces a decrease in plasma vitamin D3 half-life and increased biliary excretion of polar metabolites. ${ }^{5}$ Furthermore, liver microsomes isolated from phenobarbitone-treated animals rapidly convert vitamin D3, 25- $\mathrm{OHD}_{3}$, and $1,25(\mathrm{OH})_{2} \mathrm{D}_{3}$ to polar products rather than to active metabolites. ${ }^{56}$ Reduced 25-OHD levels have been reported in epileptics treated with phenobarbitone, diphenylhydantoin, or primidone. ${ }^{7-10}$

The results of the present study confirm the previous observations. Low serum 25-OHD level was associated with administration of anticonvulsants and overt rickets developed in the patients in hospital being given drugs, although the most important drug could not be identified. Since rickets was found only in the children with the lowest 25-OHD levels despite an average vitamin D intake, vitamin $\mathrm{D}$ dependency may be an important aetiological factor. Anticonvulsant drugs may exacerbate this state, but they cannot be considered as the main cause of rickets, because none of the outpatients showed clinical evidence of rickets when biochemical and roentgenological examinations were performed.

The serum 25-OHD level can easily be varied by vitamin D intake and exposure to sunlight. A positive correlation between vitamin $\mathrm{D}$ intake and serum 25-OHD level has been reported both in epileptics and normal subjects. ${ }^{11}$ On the other hand, the effect of ultraviolet light was shown to be equivalent to the oral vitamin D dose of 8000 to 12000 IU daily, ${ }^{12}$ and seasonal variation in serum 25-OHD levels ${ }^{13}$ appears to be due to the effect of ultraviolet light exposure. It is difficult to find out which is the more important factor for the serum 25-OHD level. In this regard, it was interesting that in one report rickets developed in epileptic patients despite a sufficient dose of oral vitamin $\mathrm{D},{ }^{14}$ and that in another report, the serum $\mathrm{Ca}$ concentration was lower in epileptic patients who worked indoors than in those who worked outside. ${ }^{15}$ Although no 25-OHD findings were given in these reports, they suggest that exposure to sunlight is important for the prevention of rickets. The present study also shows that lack of sunlight depresses serum 25-OHD level even though vitamin $\mathbf{D}$ intake may be adequate.

In conclusion, several factors-such as anticonvulsant medication, low vitamin $\mathrm{D}$ intake, and physical inactivity-may contribute to the development of rickets in severely handicapped children and the lack of sunlight should be seriously considered.

\section{References}

1 Livingston S, Berman W, Pauli L L. Anticonvulsant drugs and vitamin D metabolism. JAMA 1973; 224: 1634-6.

2 Weisman Y, Fattal A, Eisenberg Z, Harel S, Spirer Z, Harell A. Decreased serum 24, 25-dihydroxy vitamin D concentrations in children receiving chronic anticonvulsant therapy. Br Med J 1979; ii: 521-3.

3 Belsey R E, DeLuca H F, Potts J T, Jr. A rapid assay for 25-OH-vitamin $\mathrm{D}_{3}$ without preparative chromatography. $J$ Clin Endocrinol Metab 1974; 38: 1046-51.

4 Wright $\mathbf{J}$ A. Trinuride in the treatment of major epilepsy. Epilepsia 1965; 6: 67-74.

5 Hahn T J, Birge S J, Scharp C R, Avioli L V. Phenobarbital-induced alterations in vitamin $\mathrm{D}$ metabolism. J Clin Invest 1972; 51 : 741-5.

${ }^{6}$ Hahn T J, Haid S D, Halstead L R. Phenobarbitalinduced alterations in hepatic metabolism of 1,25 dihydroxycholecalciferol (DHC) (abstract). Clin Res 1973; 21 : 626.

7 Hahn T J, Hendin B A, Scharp C R, Haddad J G, Jr. Effect of chronic anticonvulsant therapy on serum 25-hydroxycalciferol levels in adults. $N$ Engl J Med 1972; 287: $900-4$.

8 Tolman K G, Jubiz W, Sannella J J, et al. Osteomalacia associated with anticonvulsant drug therapy in mentally retarded children. Pediatrics 1975 ; 56: 45-51.

9 Bouillon R, Reynaert J, Claes J H, Lissens W, De Moor P. The effect of anticonvulsant therapy on serum levels of 25-hydroxy-vitamin D, calcium, and parathyroid hormone. J Clin Endocrinol Metab 1975; 41 : 1130-5.

10 Winnacker J L, Yeager H, Saunders J A, Russell B, Anast C S. Rickets in children receiving anticonvulsant drugs. Am J Dis Child 1977; 131 : 286-90.

11 Hahn T J, Hendin B A, Scharp C R, Boisseau V C, Haddad J G, Jr. Serum 25-hydroxycalciferol levels and bone mass in children on chronic anticonvulsant therapy. N Engl J Med 1975; 292: 550-4.

12 Stamp T C B, Haddad J G, Jr, Twigg C A. Comparison of oral 25-hydroxycholecalciferol, vitamin $\mathrm{D}$, and ultraviolet light as determinations of circulating 25hydroxyvitamin D. Lancet 1977 ; i: 1341-3.

13 Stamp T C B, Round J M. Seasonal changes in human plasma levels of 25-hydroxyvitamin D. Nature 1974; 247 : 563-5.

14 Lifshitz F, Maclaren N K. Vitamin D-dependent rickets in institutionalized, mentally retarded children receiving long-term anticonvulsant therapy. I. A survey of $\mathbf{2 8 8}$ patients. J Pediatr 1973; 83: 612-20.

15 Richens A, Rowe D J F. Letter: Anticonvulsant osteomalacia. $\mathrm{Br}$ Med J 1971; iv : 684.

Correspondence to Dr Y Morijiri, Department of Paediatrics, School of Medicine, Kanazawa University, Takaramachi 13-1, Kanazawa, Japan 920.

Received 18 March 1980 